ROCZNIKI KULTUROZNAWCZE

Tom X, numer $4 \quad-\quad 2019$

DOI: http://dx.doi.org/10.18290/rkult.2019.10.4-4

JOANNA SOSNOWSKA

\title{
CISZA W MEDIACH AUDIOWIZUALNYCH
}

\section{WSTĘP}

Problematyka ciszy w mediach jest nowym i bardzo interesującym obszarem badawczym. Mimo że media audiowizualne dają dużą możliwość wykorzystywania ciszy jako elementu warsztatu dziennikarskiego i niezwykle sugestywnego środka wyrazu, badacze częściej zwracają uwagę na zjawisko hałasu, „szumu” medialnego niż znaczenie ciszy w mediach. Artykuł jest próbą zmierzenia się z problematyką ciszy w mediach audiowizualnych, które oddziałują na różne zmysły odbiorcy i mogą w sposób wielowymiarowy wykorzystywać ciszę w przekazie medialnym. Przedstawiona została typologia ciszy i jej znaczenie w życiu człowieka na podstawie źródeł psychologicznych, pedagogicznych, komunikacyjnych, antropologicznych oraz estetycznych. Jedocześnie wskazane zostały medioznawcze analizy środków przekazu pod kątem dominującej roli hałasu we współczesnych mediach. Stworzona została lista możliwości wykorzystania ciszy w mediach audiowizualnych jako środka wyrazu i ukazana różnorodność jej postaci (milczenia, pauzy, medytacji, kontemplacji, przemilczenia, pominięcia, zawieszenia, wyciszenia). Zaproponowane rozważania mogą być wykorzystane do przyszłych badań analizujących konkretne przypadki wykorzystania ciszy $\mathrm{w}$ mediach $\mathrm{w}$ różnorodnych podkategoriach typologicznych ciszy lub gatunkowych i tematycznych mediów audiowizualnych.

Dr JoAnNa SoSNOwSKA - Katolicki Uniwersytet Lubelski Jana Pawła II, Wydział Nauk Społecznych, Instytut Dziennikarstwa i Zarządzania, Katedra Komunikacji Wizualnej i Nowych Mediów; adres do korespondencji: Aleje Racławickie 14, 20-950 Lublin — e-mail: joannus@ autograf.pl. ORCID: https://orcid.org/0000-0001-8057-8571. 


\section{ZNACZNIE I PRÓBY TYPOLOGII CISZY}

Cisza jest jedną z najpierwotniejszych potrzeb człowieka. Współcześnie okazuje się najbardziej pożądanym zjawiskiem na świecie, stając w kontrze do hałaśliwego, multisensorycznego świata. Pojęcie ciszy zaczyna być przedmiotem zainteresowania wielu dyscyplin, stając się kategorią interdyscyplinarną. „Zainteresowanie to wynika z realiów życia w dobie przemian, cywilizacji globalnego chaosu wartości, w kulturze hałasu i absurdów". Jednocześnie cisza jest zależna od uwarunkowań kulturowych, zmiennych potrzeb społecznych. Jest zjawiskiem historycznie zmiennym ${ }^{2}$. Przez niektórych badaczy cisza w szerokim znaczeniu jest nie tylko połączniem braku efektów słuchowych i wzrokowych, ale także brakiem bodźców dotykowych. „Zero sensoryczne" poddawane jest badaniom deprywacji sensorycznej, wskazując tak na pozytywne, jak i negatywne skutki, np. długotrwałej ciszy sensorycz$n^{3} j^{3}$. Badania ciszy wskazują na trzy główne płaszczyzny badawcze: cisza w znaczeniu ontologicznym, aksjologicznym i semantycznym ${ }^{4}$.

Cisza jest pojęciem wieloznacznym, posiadającym bogate odniesienia synonimiczne.

Wieloaspektowe znaczenie ciszy według Teresy Olearczyk ${ }^{5}$ :

- cisza jako środowisko dla człowieka, który żyje w wielkomiejskim gwarze lub „w naturze”, którą sam niszczy bądź chroni. Cisza jako element ekologii;

- cisza jako element kultury, obyczajów, zachowań, to określony sposób bycia i obycia zmieniający się wraz z przemijającym czasem;

- cisza jako pewna metafizyczna rzeczywistość ludzka, związana z narodzinami, istnieniem, śmiercią;

\footnotetext{
${ }^{1}$ Teresa OlEarczyk, Pedagogika ciszy (Kraków: Wyższa Szkoła Filozoficzno-Pedagogiczna „Ignatianum” \& Wydawnictwo WAM, 2010), 6

2 Agnieszka JANIAK, „Komunikacyjna wartość ciszy”, w: Oblicza komunikacji. Perspektywy badań nad tekstem, dyskursem i komunikacja, red. Irena Kamińska-Szmaj, Tomasz Piekot \& Monika Zaśko-Zielińska, t. I (Kraków: Krakowskie Towarzystwo Popularyzowania Wiedzy o Komunikacji Językowej „Tertium”, 2004), 40

${ }^{3}$ Por. Jan Strelau, „Różnice indywidualne: opis, determinanty i aspekt społeczny”, w: Psychologia. Podręcznik akademicki, red. J. Strelau (Gdańsk: Gdańskie Wydawnictwo Psychologiczne, 2000), 664

${ }^{4}$ Por. Przestrzeń ciszy. Przestrzenie wizualne i akustyczne czlowieka. Antropologia audiowizualna jako przedmiot i metoda badań, red. Agnieszka Janiak \& Justyna Harbanowicz (Wrocław: Wydawnictwo Naukowe Dolnośląskiej Szkoły Wyższej, 2011.

${ }^{5}$ Głównie jako przedmiot badań filozofii i pedagogiki w OlearCZyK, Pedagogika ciszy.
} 
- cisza jako wartość, zajmująca pewne miejsce w hierarchii wartości, ludzkich możliwości i potrzeb;

- cisza jako element życia duchowego; poprzez duchowość możemy mieć dostęp do życia wewnętrznego, duchowego.

Jak podaje Agnieszka Janiak ${ }^{6}$, cisza może być rozpatrywana również na dwóch poziomach: strukturalnym i funkcjonalnym. Na poziomie strukturalnym cisza jest elementem komunikacji przedmiotowej poprzez:

- prowadzenie do duchowego oczyszczenia, autoanalizy; jest metodą doskonalenia wewnętrznego, niezbędnym warunkiem przeżycia mistycznego, spotkania z Bogiem;

- umożliwienie oczyszczenia umysłu, otwarcia na poznanie, możności uzupełniania wiedzy, doznań, dochodzenia do prawdy i mądrości; jest elementem aksjologicznego poznania; metodą poznawczą;

- umiejętność myślenia dyskursywnego; koncentracji myśli, uwolnienia się od chaosu; racjonalizacji i refleksji;

- umiejętność pełnego postrzegania świata, wyostrzenia zmysłów na dźwięki, zapachy, smaki, obrazy; oswojenia rzeczywistości, powrotem do natury; odejściem od znieczulenia i braku wrażliwości;

- metodę selekcji; umożliwienie procesu dostrzegania, koncentracji na istotnych sprawach;

- sprzyjaniu wyobraźni; twórczemu przekształcaniu świata i rzeczywistości.

Na drugim z rozpatrywanych poziomów - funkcjonalnym - cisza jest elementem komunikacji osobowej, realizując się także na kilka sposobów:

- jako narzędzie oczyszczania mowy, unikania słowotoku; z poziomu komunikacji werbalnej przechodzimy poziom empatyczny;

- jako brak słowa, staje się autonomicznym, ekspresyjnym komunikatem nadawcy;

- jako element integrujący grupę społeczną (akt religijny, rytualny, obyczajowy, kulturowy)

- jako element introspektywny, personalistyczny;

- jako element higieny psychofizycznej.

Poprzez ciszę możliwa jest komunikacja, która jest zależna od umiejętności jej wykorzystania i odpowiednich kompetencji odczytania ciszy. Cisza

\footnotetext{
${ }^{6}$ JANIAK, ,Komunikacyjna wartość ciszy”, 45
} 
absolutna, która jest odpowiednikiem braku dźwięku, w naszej komunikacji nie istnieje, ,jest martwą ciszą przestrzeni kosmicznej, całkowicie abstrakcyjną"7. Cisza może mieć charakter:

- introwertyczny (medytacyjny) - przeżywania emocji;

- konfrontacyjny (dialogiczny) - wyrażania emocji;

Jan F. Jacko opisuje typologię ciszy, wskazując na dziewięć głównych typów ciszy ${ }^{8}$ :

1. Cisza jako brak bodźców słuchowych (cisza absolutna, brak fal dźwiękowych, niezwykle rzadka forma).

2. Cisza jako brak bodźców (cisza wizualna, dotykowa, smakowa, emocjonalna itp.).

3. Cisza jako brak znaków (brak możliwości identyfikacji funkcji znakowych w komunikacie, np. szumie ulicy).

4. Cisza jako milczenie (brak oczekiwanej odpowiedzi muzycznej, dźwiękowej, słownej).

5. Cisza jako brak szumu percepcyjnego w danym kanale (brak zakłóceń pozwalający odróżnić komunikat od kontekstu).

6. Cisza jako brak budzący dyskomfort lub przeszkadzający (brak bodźców przeszkadzających w percepcji i akcie komunikacji).

7. Cisza jako harmonia i konsekwencja stylu (brak hałasu form, harmonia treści i formy).

8. Cisza jako niezrozumiałość bodźców (brak zrozumienia i interpretacji komunikatu):

a) cisza jako szum informacyjny (bełkot, natłok),

b) cisza jako niezrozumiałość znaków z kodu komunikatu (różnorodność kodów komunikacyjnych, np. międzykulturowych),

c) cisza jako znaki innego kodu (zamienność kodu werbalnego i niewerbalnego).

9. Cisza jako wyciszenie wewnętrzne (skupienie jako aktywna postać umysłu):

a) wyciszenie wewnętrze a kody arbitralne (wyciszenie wpływu kodów arbitralnych na percepcję i emocje),

\footnotetext{
${ }^{7}$ Ibid., 42

${ }^{8}$ Jan F. FACKO, „Cisza jako pojęcie analogiczne. Próba analizy ontologiczno-semiotycznej”, w: Przestrzeń ciszy. Przestrzenie wizualne i akustyczne czlowieka. Antropologia audiowizualna jako przedmiot i metoda badań, red. Agnieszka Janiak \& Justyna Harbanowicz (Wrocław: Wydawnictwo Naukowe Dolnośląskiej Szkoły Wyższej, 2011), 13-20
} 
b) wyciszenie jako warunek poznania (uwolnienie się od bodźców, zbędnego zaangażowania),

c) wyciszenie jako imperatyw moralny (dystans i otwarcie na rzeczywistość),

d) wyciszenie jako warunek kontemplacji religijnej.

Problematyka ciszy rozpatrywana jest również przez badaczy sztuki, wskazujących na specyficzne znaczenie tego środka wyrazu artystycznego i czynnika budującego relację nadawcy z odbiorcą. Patrice Pavis wymienia cztery rodzaje milczenia w teatrze (jako analogię ciszy) ${ }^{9}$ :

- milczenie znaczące (jako tłumienie przez osobę rzeczywistego sensu słów w znaczeniu psychologicznym),

- milczenie alienacyjne (jako wyobcowanie jednostki poprzez nieumiejętne przekazanie sensu słów),

- milczenie metafizyczne (jako niemożność ludzkiego porozumienia),

- milczenie rozgadane (jako milczenie połączone z pozornymi dialogami).

Powyższe wybrane opisy i typologie ciszy wskazują na jej wieloaspektowy i wielowymiarowy charakter. Badania związane $\mathrm{z}$ ciszą $\mathrm{w}$ mediach są zatem dużym wyzwaniem i niezwykle interesującym obszarem analiz. Problematyka naukowa $\mathrm{w}$ badaniach medioznawczych częściej bowiem dziś opisuje hałas (szum medialny), niż zajmuje się kwestią ciszy w przekazanie medialnym.

\section{HAŁAS JAKO ZJAWISKO MEDIALNE}

Żyjemy w świecie zatruwanym hałasem, w którym cisza stała się towarem luksusowym, coraz bardziej pożądanym. Z badań audiologicznych wynika $^{10}$, że już jedna godzina spędzona $w$ dużym hałasie niszczy układ nerwowy człowieka i potrzeba aż ośmiu godzin, aby wrócić do stabilizacji organizmu. Hałas wpływa na brak koncentracji, rozkojarzenie, a także powoduje nieumiejętność prawidłowego odczytywania informacji (również emocji). Wśród ważnych przyczyn rozwoju epoki hałasu figurują media. Przestrzeń

\footnotetext{
${ }^{9}$ Patrice PAVIS, Stownik terminów teatralnych, przeł. Sławomir Świontek (Wrocław: Ossolineum, 2002), 290-292.

${ }^{10}$ Zob. Krystyna PAWLAS, „Hałas jako czynnik zanieczyszczający środowisko - aspekty medyczne”, Medycyna Środowiskowa - Environmental Medicine 18, no. 4 (2015): 49-56.
} 
medialna jest zdominowana przez hałas, szybkie tempo przekazywania treści, intensywność obrazową i dźwiękową. Według badaczy „drugi potop” (potop informacyjny) jest wynikiem kakofonii, ogłuszającego jazgotu mediów i narastającej wojny obrazów ${ }^{11}$. Współczesne media potęgują rosnące tempo życia, liczbę zmian i chaosu informacyjnego ${ }^{12}$. Szczególnie treści audiowizualne oparte są na budowaniu esencjonalnego dzieła medialnego. Świat wypełniony jest „wrzaskiem informacyjnego rynku” ${ }^{13}$. Wielu badaczy mówi o zaczadzeniu czy smogu danych ${ }^{14}$. Odbiorca zmuszony jest do wzmożonego wysiłku, który trzeba włożyć zarówno w akt zrozumienia treści komunikatu, jak też jego odpowiedniej selekcji. „Zarządzanie informacją” staje się wyzwaniem współczesnego świata i niezbędną kompetencją odbiorcy mediów. Media potęgują swoją hałaśliwością zjawisko tzw. desensytyzacji, czyli znieczulenia (znieczulenie na bodźce, które są pożądane z punktu widzenia relacji społecznych, międzyludzkich) ${ }^{15}$. Wpływa to negatywnie na proces komunikowania, krytycznego myślenia i odczytywania emocji. Przeciążenie informacyjne towarzyszy stresowi informacyjnemu. Jak zauważa Maria Ledzińska, ,zjawiska nadprodukcji informacji i naporu przyspieszenia są ujmowane w kategoriach stresu psychologicznego"16. Tylko w warunkach optimum informacyjnej stymulacji człowiek może funkcjonować efektywnie. Alokacja uwagi, wyciszenie, selektywność treści może pomóc we właściwym odbiorze i przetwarzaniu treści medialnych. We współczesnym świecie mediów jest jednak sytuacją nierealną ${ }^{17}$. Intensywne bodźcowanie medialne są wieloaspektowym problemem społecznym, psychologicznym i zdrowotnym.

Widać wyraźne zmiany w sposobie odbioru i nadawania treści medialnych. Radio stało się medium towarzyszącym, które musi zabiegać o uwagę

\footnotetext{
${ }^{11}$ Por. Pierre LÉVy, „Drugi potop”, za: Nowe media w komunikacji społecznej w XX wieku. Antologia, red. Maryla Hopfinger (Warszawa: Oficyna Naukowa, 2002), 373-379.

12 Rafael BALL, „The Scientific Information Environment in the Next Millennium”, Library Management 21, no. 1 (2000): 10-12.

${ }^{13}$ Wiesław BABIK, „O natłoku informacji i związanym z nim przeciążeniu informacyjnym”, Uniwersytet Pedagogiczny im. Komisji Edukacji Narodowej w Krakowie. Sympozjum CZŁOwIEK - MEDIA - EDUKACJA (archiwum 2010-2014), dostęp 22.02.2020, http://www.ktime.up.krakow.pl/ ref2010/babik.pdf.

${ }^{14}$ David SHENK, Data smog: Surviving the Information Glut (New York: HarperOne, 1997).

${ }^{15}$ Ibid.

${ }^{16}$ Maria LEDZIŃSKA, „Stres informacyjny jako zagrożenie dla rozwoju”, Roczniki Psychologiczne 5 (2002): 80.

${ }^{17}$ Maria LEDZIŃSKA, Człowiek współczesny $w$ obliczu stresu informacyjnego (Warszawa: Instytut Psychologii PAN, 2009).
} 
słuchacza, konkurując z innymi dźwiękami i obrazami medialnymi ${ }^{18}$. Zmniejszony format ekranu na tablecie i telefonie zmienia sposób dotarcia do odbiorcy. Z drugiej strony wielkie widowiska sportowe, gigantyczna produkcja filmów i seriali powodują rozwój nowych technologii, w tym lepszej jakości obraz i dźwięk oraz coraz większe ekrany telewizyjne. Nowy odbiór mediów związany jest też ze zjawiskiem multiscreeningu. $Z$ badań wynika, że $83,2 \%$ polskich internatutów to multi-screenerzy, czyli osoby jednocześnie korzystające z kilku ekranów (telewizora, laptopa, smartfona, komputera stacjonarnego, tabletu, Smart TV, konsoli do gier, czytnika e-booków oraz phabletu) $^{19}$. Częstotliwość i regularność takich zachowań rośnie, a prezentowane treści nakładają się na siebie i jednocześnie stymulują do odpowiednich reakcji. Powoduje to jeszcze większy ,potop informacyjny” i tworzenie bezrefleksyjnych odruchów zachowawczych. Jedocześnie, przez rozwój technologiczny wykorzystujący narzędzia niezbędne dla współczesnego odbiorcy, potęgowana jest interaktywność medialna. Znane widzom gatunki audiowizualne stają się formami hybrydowymi, łączącymi klasyczne formy z mediami społecznościowymi, aplikacjami czy technologią gier komputerowych.

Forma interaktywna zakłada aktywność widza i reaguje na zmiany nawyków i zachowań nowoczesnej widowni, wyposażonej w smartfony, tablety i komputery, przyzwyczajonej do nieustannego klikania, bezpośredniego reagowania na odbierane treści, a także dzielenia się własnymi doświadczeniami i spostrzeżeniami poprzez publikację zdjęć czy nagrań wideo ${ }^{20}$.

Według naukowców poziom krytyczny „hałasu medialnego” oscyluje na granicy 100000 słów i 43 gigabajtów informacji na dobę ${ }^{21}$.

Słowotok jest zagrożeniem globalnym, cywilizacyjnym, za które ponoszą odpowiedzialność środki masowego przekazu. W nadmiarze słów ginie sens istnienia człowieka i istnienia świata; ginie też sens samego słowa, którego multiplikacja pociąga za sobą autodestrukcję ${ }^{22}$.

\footnotetext{
${ }^{18}$ Por. Tomasz GoBan-KLAS, Media i komunikowanie masowe (Warszawa: Wydawnictwo Naukowe PWN, 2005),

${ }^{19}$ „Multiscreening powszechny wśród internautów”, Wirtualnemedia, dostęp 19.02.2020, https://www.wirtualnemedia.pl/artykul/multiscreening-powszechny-wsrod-internautow-w-gore-shiftinginfografika\#.

${ }^{20}$ Joanna SOSNOwSKA, „Serial interaktywny”, w: Jakie media? Konteksty-badania-postulaty, red. Justyna Szulich-Kałuża \& Olga Białek-Szwed (Lublin: Wydawnictwo KUL, 2019), 68-75.)

${ }^{21}$ Jordi García-OJalvo \& José Sancho, Noise in Spatially Extended Systems (New York: Springer, 1999).

${ }^{22}$ Iwona Gralewicz-Wolny, Pisz o milczeniu. Świat poetycki Anny Kamieńskiej (Katowice: Gnome, 2002), 29.
} 
Adam Lepa wskazuje na elementy zakłócające ciszę w mediach i wpływające negatywnie na odbiór przekazu medialnego. Zalicza do nich:

- napastliwą propagandę medialną,

- stosowanie w debatach argumentu siły, a nie siły argumentu,

- przekrzykiwanie się z użyciem inwektyw i słów obelżywych,

- nieustanne „bombardowanie” ze strony dysponentów informacji,

- biegunkę słowną,

- dyktaturę emocji.

\section{CISZA W MATERIAŁACH AUDIOWIZUALNYCH}

Dalsze rozważania są próbą zebrania problematyki ciszy w mediach audialnych i wizualnych oraz wskazania obszarów, w których cisza jest lub może być wykorzystywana. Media audiowizualne są środkami społecznego przekazu komunikowania, które oddziałują zarówno na zmysły wzroku, jak i słuchu ${ }^{23}$. Dlatego podstawowym ich tworzywem jest „słowo, obraz (statyczny albo dynamiczny), muzyka, hałas i cisza" 24 .

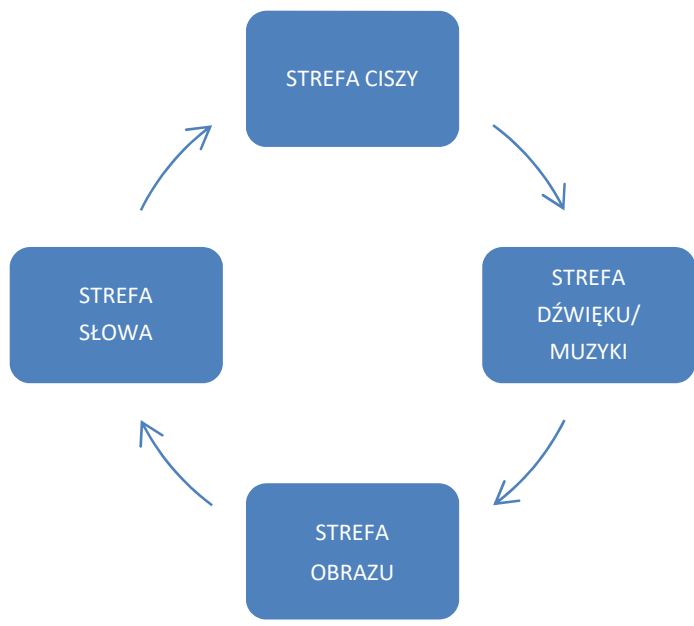

Rys. 1. Zależność istnienia ciszy w mediach audiowizualnych (opracowanie własne)

\footnotetext{
${ }^{23}$ Zob. Małgorzata LASKOwSKA, „Oddziaływanie i wpływ mediów audiowizualnych: zarys problematyki”, Studia Ełckie 14 (2012): 351-360.

${ }^{24}$ Adam LePA, Pedagogika mass mediów (Łódź: Archidiecezjalne Wydawnictwo Łódzkie, 2000), 213
} 
Media audiowizualne dają dużą możliwość wykorzystywania ciszy jako elementu warsztatu dziennikarskiego i niezwykle sugestywnego środka wyrazu. Jako zabieg artystyczny, warsztatowy jest zamierzonym działaniem, mającym na celu wywołanie odpowiedniej reakcji odbiorcy. Cisza może mieć różnorodną postać: milczenia, pauzy, medytacji, kontemplacji, przemilczenia, pominięcia, zawieszenia, wyciszenia. W przekazie medialnym cisza nie jest wprost synonimem nieobecności czy pustki, jest specyficzną formą zaistnienia znaczeń i emocji, które nie są możliwe do wytworzenia poprzez inne środki wyrazu.

W znaczeniu twórczego, celowego użycia może być:

- działaniem, dzięki którym dochodzą do odbiorcy pojedyncze dźwięki natury, otoczenia (np. szmery, skrzypienie, szum);

- tworzeniem odpowiedniej przestrzeni dla słowa mówionego (możliwością wypowiedzenia bohatera, narracji lektora);

- kontrą dla krzyku, hałasu, komentarza, narracji (odpowiednim połączeniem elementów wyrazistych dźwiękowo z ciszą, wyciszeniem),

- przestrzenią dla ekspozycji obrazu (proporcja między obrazem a słowem mówionym - np. odpowiednie eksponowanie obrazu symbolu: płacząca twarz, pot na czole itp.);

- językiem komunikacji niewerbalnej, która jest bardzo bogata i oparta na ciszy słownej (często wykorzystywany do konstruowania emocjonalnej strony dzieła medialnego - wywiadu, reportażu czy newsa);

- wyostrzeniem kontrastu, dzięki czemu wzmacnia dźwięk, słowo, obraz (np. niemy krzyk na ekranie, pauza w rozmowie);

- wymownym milczeniem zarówno w przekazie audialnym, jak też audiowizualnym (niewygodne pytania, wzruszenie, brak słów, urwana wypowiedź);

- elementem konstrukcji medialnego dzieła audiowizualnego (m.in. rytm montażowy);

- wyraźnym znakiem dla odbiorcy: końca, przecinka, wielokropka czy wykrzyknika (odpowiednie znaki przystankowe w dźwięku i obrazie);

- pauzą - wyraźnym elementem sztuki przestankowania (proporcja między częściami komunikatu medialnego);

- dramatyzowaniem przekazu medialnego (celowym zerwaniem toku narracji, nadmiernym wprowadzaniem pauzy lub kontrastowania obrazu i dźwięku);

- wyciszaniem - stopniowym uciszaniem poszczególnych dźwięków, muzyki, narracji słownej; 
- środkiem uwypuklającym, nagłaśniającym (koncentrującym uwagę widza na odpowiednią część komunikatu medialnego, silnie wzmacniającym treść).

Cisza wywołuje emocje świadomie, w odróżnieniu do wywoływania emocji przez inne zabiegi twórcze, które częściej mają działanie niezamierzone. Semantyka ciszy wymaga kontekstu i odpowiedniego potencjału percepcyjnego zaangażowania odbiorców. Jest elementem twórczym, pozwalającym w innowacyjny sposób budować emocje, przekazywać treści, wprowadzać symbolikę. Cisza tworzy napięcie w przekazie medialnym, często o większej wyrazistości niż inne środki wyrazu. Może być „ciszą przed burzą”, urwaniem wypowiedzi, zawieszeniem, może wprowadzać niepokój, nienaturalność przekazu. Jest ważnym elementem harmonii dzieła wizualnego. Nadaje odpowiedni rytm i buduje strukturę przekazu. Wzmacnia możliwość prawidłowego odbioru. Daje możliwość trenowania uważności, wyszukiwania znaczeń obrazowych, dźwiękowych oraz rozumienia słowa. W sposób zamierzony może być też elementem zadumy, zamyślenia, np. w kontekście tematów śmierci czy cierpienia. W wielu przypadkach jest elementem dialogicznym, budującym dwustronny komunikat ${ }^{25}$. Poprzez celowe działanie jest też autonomicznym komunikatem, który może samodzielnie wyrażać określone treści. Jest środkiem pozostawiającym miejsce dla wyobraźni i refleksji odbiorcy. Cisza obejmuje też kontekst milczenia, które jest jedną z postaci ciszy.

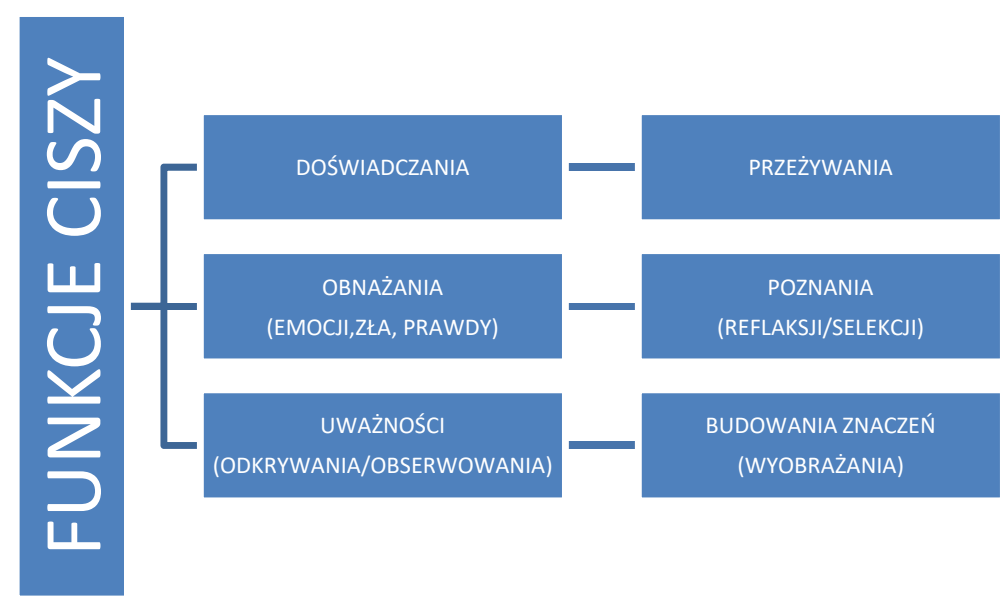

Rys. 2. Funkcje ciszy w mediach (opracowanie własne)

\footnotetext{
${ }^{25}$ Zob. Przestrzeń ciszy, 8.
} 
Milczenie w przekazie medialnym ma bardzo wyraźne znaczenie, dając wyraz zadumie, skrępowaniu czy niechęci. W niektórych przypadkach milczenie jest silniejszym i lepszym środkiem wyrazu niż słowo. Cisza wymusza też odpowiednie kompetencje odbiorcze, wprowadzając nietypowy odbiór treści medialnych poprzez narzucenie ciszy wewnętrznej (wyciszenia) czy rozumienia wielowymiarowego. Kompetencje te wydają się bliższe odbiorowi dzieła sztuki (utworu muzycznego, filmu) niż znanych kompetencji medialnych.

\section{WYMIARY CISZY W MEDIACH}

Problematyka ciszy w mediach może być również rozpatrywana w wielu kontekstach pozawarsztatowych. Na potrzebę ciszy jako elementu etyki medialnej oraz edukacji medialnej wskazywał Adam Lepa. Zauważył, że cisza jest wartością i widoczne jest „rosnące zapotrzebowanie człowieka na ciszę oraz wysiłki, aby ukazać walory ciszy i szerokie możliwości ich wykorzystania" ${ }^{26}$. Słowo uznaje za solidarne z ciszą, podkreślając metodę komunikowania „cisza i słowo”, ułatwiającą tworzenie zorganizowanego środowiska ciszy (galenosfery) ${ }^{27}$. Warstwa ciszy powinna współistnieć z pozostałymi warstwami: ikonosferą (warstwą obrazu), logosferą (warstwą słowa) oraz sonoferą (warstwą dźwięku). Wysuwa postulaty tworzenia programów edukacyjnych uwrażliwiających na ciszę w mediach oraz świadome tworzenie przekazów medialnych z poszanowaniem ciszy.

Etyczny wymiar ciszy jest wyraźnie widoczny w braku reakcji mediów na określone sprawy społeczne, kulturalne, polityczne czy religijne. Przemilczenie, cisza medialna może ukazywać nie tylko brak zaangażowania, lecz wręcz niewypełnianie obowiązku misji dziennikarskiej. Przykładem mediów zaangażowanych przerywających milczenie są media obywatelskie (Loud Silence media, Breaking the Silence), formy dziennikarstwa śledczego czy reportaży interwencyjnych. Cisza medialna jest również uszanowaniem godności osoby, powagi wydarzenia czy sytuacji nadzwyczajnych (katastrofa, śmierć). Cisza symboliczna spowodowana rocznicami, wydarzeniami okolicznościowymi ma wymiar wyjątkowy. Nietypową akcją medialną było „70 sekund na 70 rocznicę wybuchu Powstania Warszawskiego”, kiedy stacje telewizyjne i radiowe wyemitowały w piątek o godz. 17 spot 70 sekund

\footnotetext{
${ }^{26}$ Adam LEPA, „Etyka ciszy w edukacji medialnej”, Lódzkie Studia Teologiczne 21 (2012): 144.

${ }^{27}$ Ibid., 145
} 
dla Powstańców, w którym ciszę przeplatały archiwalne odgłosy walk powstańczych nagrane 70 lat temu na ulicach Warszawy ${ }^{28}$. Minutą ciszy w rozgłośniach radiowych została upamiętniona śmierć Jana Pawła II (godz. 21:37). Drugi Program Polskiego Radia prowadził akcję protestacyjną „24 godziny milczenia", w ramach której punktualnie o 6:00 rano umilkły klasyczne utwory wielkich kompozytorów w radiowej „Dwójce” ${ }^{29}$. Niezwykle trudna dla mediów jest cisza niezaplanowana, wywołana sytuacjami nadzwyczajnymi. Jej przykładem jest katastrofa smoleńska z 2010 r., kiedy stacje informacyjne nadające na żywo musiały zmierzyć się z ogromnym ładunkiem emocjonalnym dziennikarzy i gości studyjnych. Jak wspominał Jarosław Kuźniar, ówczesny dziennikarz TVN24: „Nie wiedziałem, że to będzie takie trudne, że będzie tam tyle ciszy" ${ }^{\prime 3}$. Z ciszą medialną mamy do czynienia również podczas wyborów, które narzucają „,ciszę wyborczą”, zakazując nadawania okołowyborczych komunikatów politycznych.

Problematyka wartości milczenia (ciszy) i słowa była przedmiotem orędzia z okazji Dnia Środków Społecznego Przekazu w 2012 r. ${ }^{31}$ Zwracając się do ludzi mediów, papież Benedykt XVI wskazał, że:

- milczenie jest integralną częścią komunikacji i nie istnieją bez niego słowa bogate w treść;

- cisza buduje dialog z drugim człowiekiem;

- w rozmowie milczenie pozwala dostrzec emocje ,wyraz twarzy, gest, malujące się na twarzy zmartwienie czy ból";

- cisza ułatwia sformułowanie niebanalnych odpowiedzi na pojawiające się pytania;

- współczesne media są zagrożeniem dla wartości ciszy;

- komunikacja medialna wprawia jednostkę w stan oszołomienia, a nadmiar informacji z mediów rodzi iluzję zaspokajania podstawowych potrzeb.

Wcześniej również papież Jan Paweł II dostrzegał wartość ciszy, widząc w niej dobro współcześnie coraz rzadsze. „Rozwój komunikacji i wymiany informacji we współczesnym społeczeństwie stwarza niekiedy niebezpie-

${ }^{28}$ „70 sekund ciszy na 70-lecie Powstania”, Polska, dostęp 21.02.2020, https://polskatimes.pl/ 70-sekund-ciszy-na-70lecie-powstania-o-godz-17-wspolnie-oddajmy-hold-bohaterom/ar/3526051.

${ }^{29}$ „Kultura w zagrożeniu!”, Polskie Radio, dostęp 22.02.2020, https://www.polskieradio.pl/ 8/193/Artykul/174550,Kultura-w-zagrozeniu.

30 „To miała być spokojna sobota. Tak dowiedzieliśmy się o katastrofie”, TVN24, dostęp 22. 02.2020, https://tvn24.pl/wiadomosci-z-kraju,3/katastrofa-smolenska-tak-wygladal-poranek-w-studiutvn24, 531594.html?h=20b7.

${ }^{31}$ Por. BenEDYKT XVI, „Milczenie $i$ stowo droga ewangelizacji. Orędzie na XLVI Światowy Dzień Środków Społecznego Przekazu”, L’Osservatore Romano 33, nr 3 (341) (2012): 7-9. 
czeństwo, że zabraknie miejsca na skupienie, a ludzie staną się niezdolni do refleksji" ${ }^{32}$. Jednym z wyzwań medialnych była 45 -minutowa papieska modlitwa w ciszy na Wawelu podczas transmisji radiowej i telewizyjnej. „Sprawozdawcy radiowej Jedynki byli zachwyceni tym, że po raz pierwszy cisza stała się faktem i narzędziem medialnym, sposobem na głęboką komunikację międzyosobową"33.

Przedstawione rozważania ukazały, jak ważnym tematem w obecnej epoce, epoce hałasu, jest kategoria ciszy w mediach. Przestrzeń medialna jest zdominowana przez hałas, szybkie tempo przekazywania treści, intensywność obrazową i dźwiękową. Wskazane typologie ciszy, jej funkcje i wpływ na tworzenie komunikatu medialnego są wyznacznikami obszarów badania mediów w przyszłości. Może być ona zarówno kategorią badań odbioru mediów, jak również zawartości treści i estetyki w mediach audiowizualnych (telewizji, radiu, internecie). Jak wskazują badania Adama Lepy, mogą również być ważnym elementem badania etyki mediów.

\section{BIBLIOGRAFIA}

BABIK, Wiesław. „O natłoku informacji i związanym z nim przeciążeniu informacyjnym”. Uniwersytet Pedagogiczny im. Komisji Edukacji Narodowej w Krakowie. Sympozjum CZŁowIEK - MEDIA - EDUKACJA (archiwum 2010-2014). Dostęp 22.02.2020. http://www.ktime.up.krakow.pl/ ref2010/babik.pdf.

BALL, Rafael. „The Scientific Information Environment in the Next Millennium”. Library Management" 21, no. 1 (2000): 10-12

BenEDYKT XVI. „Milczenie i słowo drogą ewangelizacji. Orędzie na XLVI Światowy Dzień Środków Społecznego Przekazu”. L'Osservatore Romano 33, nr 3 (341) (2012): 7-9.

FACKO, Jan F. „Cisza jako pojęcie analogiczne. Próba analizy ontologiczno-semiotycznej”. W: Przestrzeń ciszy. Przestrzenie wizualne i akustyczne człowieka. Antropologia audiowizualna jako przedmiot i metoda badań, red. Agnieszka Janiak \& Justyna Harbanowicz, 13-20. Wrocław: Wydawnictwo Naukowe Dolnośląskiej Szkoły Wyższej, 2011.

García-OJALVo, Jordi, \& José SANChO. Noise in Spatially Extended Systems. New York: Springer, 1999.

Goban-Klas, Tomasz. Media i komunikowanie masowe: teorie i analizy prasy, radia, telewizji i Internetu. Warszawa: Wydawnictwo Naukowe PWN, 2005.

\footnotetext{
32 Jan PAWE⿺ II, „Wejść w ciszę”, L'Osservatore Romano 25, nr 9 (2004): 10.

${ }^{33}$ Marian PISARZAK, „Gesty Papieża”, Mateusz - Czytelnia, dostęp 21.02.2020, http://mateusz.pl/ czytelnia/mp-gesty.htm.
} 
Gralewicz-Wolny, Iwona. Pisz o milczeniu. Świat poetycki Anny Kamieńskiej. Katowice: Gnome, 2002.

JANIAK, Agnieszka. Komunikacyjna wartość ciszy, w: Oblicza komunikacji. Perspektywy badań nad tekstem, dyskursem i komunikacja, red. Irena Kamińska-Szmaj, Tomasz Piekot \& Monika Zaśko-Zielińska, t. I, 199-208. Kraków: Krakowskie Towarzystwo Popularyzowania Wiedzy o Komunikacji Językowej „Tertium”, 2004.

LASKOWSKA, Małgorzata. „Oddziaływanie i wpływ mediów audiowizualnych: zarys problematyki”. Studia Ełckie 14 (2012): 351-360

LEDZIŃSKA, Maria. Człowiek wspótczesny w obliczu stresu informacyjnego. Warszawa: Instytut Psychologii PAN, 2009

LEDZIŃSKA, Maria, „Stres informacyjny jako zagrożenie dla rozwoju”. Roczniki Psychologiczne 5 (2002): 77-97.

LEPA, Adam. Pedagogika mass mediów, Łódź: Archidiecezjalne Wydawnictwo Łódzkie, 2000.

LEPA, Adam. „Etyka ciszy w edukacji medialnej”. Łódzkie Studia Teologiczne 21 (2012): 143-152

LEPA, Adam. „Funkcja ciszy w wychowaniu do mediów”. Łódzkie Studia Teologiczne 18 (2009): $177-188$

LÉVY, Pierre. „Drugi potop” - cyt. za: Nowe media w komunikacji społecznej w XX wieku. Antologia, red. Maryla Hopfinger, 373-389. Warszawa: Oficyna Naukowa, 2002.

„Multiscreening powszechny wśród internautów”, Wirtualnemedia. Dostęp 19.02.2020. https://www.wirtualnemedia.pl/artykul/multiscreening-powszechny-wsrod-internautow-w-goreshifting-infografika\#.

OlearczyK, Teresa. Pedagogika ciszy. Kraków: Wyższa Szkoła Filozoficzno-Pedagogiczna „Ignatianum” \& Wydawnictwo WAM, 2010

PAvis, Patrice. Słownik terminów teatralnych. Przełożył Sławomir Świontek. Wrocław: Ossolineum, 2002.

PAWLAS, Krystyna. „Hałas jako czynnik zanieczyszczający środowisko — aspekty medyczne”. Medycyna Środowiskowa - Environmental Medicine" 18, no. 4 (2015): 49-56.

Przestrzeń ciszy. Przestrzenie wizualne i akustyczne czlowieka. Antropologia audiowizualna jako przedmiot i metoda badań, red. Agnieszka Janiak \& Justyna Harbanowicz. Wrocław: Wydawnictwo Naukowe Dolnośląskiej Szkoły Wyższej, 2011.

ShenK, David. Data Smog: Surviving the Information Glut. New York: HarperOne, 1997.

Strelau, Jan. „Różnice indywidualne: opis, determinanty i aspekt społeczny”. W: Psychologia. Podręcznik akademicki, red. Jan Strelau, t. 2, 654-662. Gdańsk: Gdańskie Wydawnictwo Psychologiczne, 2000

\section{CISZA W MEDIACH AUDIOWIZUALNYCH}

\section{Streszczenie}

Cisza jest współcześnie najbardziej pożądanym zjawiskiem na świecie, a pojęcie ciszy zaczyna być przedmiotem zainteresowania wielu dyscyplin naukowych, stając się kategoria interdyscyplinarną. Artykuł jest próbą zebrania problematyki ciszy w mediach audialnych i wizualnych oraz wskazania obszarów, w których cisza jest lub może być wykorzystywana.

Slowa kluczowe: cisza; hałas; media; media audiowizualne. 


\section{SILENCE IN AUDIOVISUAL MEDIA}

\section{Su m m ary}

Today, silence is the most desirable phenomenon in the world, and the concept of silence begins to be the subject of interest of many scientific disciplines, becoming an interdisciplinary category. The article is an attempt to gather silence in audio and visual media and to indicate areas where silence is or can be used

Key words: silence; noise; media; audiovisual media. 